\title{
Measurement of Effectiveness Training \& Development Programs in the Case of Research Affairs of Haramaya University, Oromia Region, Ethiopia Country - Empirical Study
}

\author{
Suleymen Abdureman Omer \\ Research extension and publication office, Haramaya University, Oromia Region, Ethiopia
}

\begin{abstract}
Effectiveness of training is measured in terms of development in KSA and on job performance enhancement. Here Training effectiveness is measurement based on the effective determination trainer performance and trainee performance. Different studies have evaluated the effectiveness of the training in different perspectives here is empirical studies. People are considered to be the source of competitive advantage. Many forward looking organizations are giving more emphasis to employees and their related issues. In the cut-throat competitive world, the organizations have realized that their most valuable asset is their human capital and many are convinced for large investments in employee training and development. However mere investment is not adequate; they have to ensure that the investment made will generate good returns. As a backdrop to this, the present study is undertaken to analyze training \& development effectiveness in an organization. The present study was conducted in the research affairs office of Haramaya University is one of the first and oldest institutions of the higher learning in Ethiopia. The results of the study revealed that here is a positive correlation between the four dimensions of training program- effective determination of training needs, good training design, efficient trainer and trainee performance and overall training effectiveness which is significant at 0.01 levels. This indicates that effective determination of training needs, good training design, efficient trainer and trainee performance will increase the effectiveness of the training \& development program.
\end{abstract}

Keywords: Effectiveness of Training and development, Human capital.

DOI: $10.7176 / \mathrm{JEP} / 12-07-05$

Publication date:March $31^{\text {st }} 2021$

\section{Introduction}

Haramaya University is one of the first and oldest institutions of the higher learning in Ethiopia. The University strives to be among the leading nationally and internationally recognized Universities for excellence in Teaching -Learning, Research and Community engagement. Currently, HU has been undertaking various research and outreach activities. As a pioneering institution of research and extension in Ethiopia, the university has developed and released considerable number of technologies. It has also been disseminating the generated technologies and knowledge to end users in partnership with a number of local, national, and international stakeholders.

Research Affairs Office has re-structured its research activities from the general vision of the institution and currently they are undertakings in different broad research thematic areas and they accomplished a good record of managing on different research undertakings which supported by various organizations including nationally and internationally funding organizations.

One of the main goals of training programs is to build strong, competent and qualified personnel in both the private and public sectors [1]. Taylor (1961) as cited in [1] conceptualized training as a means to bring about a continuous improvement in the quality of work performed; it would equip them with necessary knowledge, skill, abilities and attitude to perform their jobs. Capacity building training development is the process of developing the capacities building of individuals and institutions and shaping the learning processes, such that they are enabled to achieve sustainable results within their own system of reference. Capacity development facilitates change among people, in three dimensions: knowledge, skills and values/attitudes.

As educating and training the future leaders along with conducting researches on several issues of development is extremely challenging, the need for a combination of traditional and innovative capacity development measures is essentially required to deliver the knowledge products.

The modern day business organizations are reeling under intense competition and accordingly there are dramatic changes in the approaches adopted by the organizations to survive and excel in this competitive world. Human capital is a major weapon used by organizations as it is considered to be a source of competitive advantage. This competitive advantage can be made sustainable only when human capital is knowledgeable and dexterous. Training and Development function ensures that human capital inculcates required knowledge and abilities. The organizations have long understood that their most valuable asset is their human capital and many are convinced for large investments in employee training and development [2].

Organizational training activities are capable of becoming sources of competitive advantage [3] through 
their positive impact on employees ${ }^{e e}$ productivity [4] and their contribution to business objectives [5]. It is an undisputed fact that effective training is considered to be an investment in the human resources of an organization that yields both immediate and long -range returns. However mere investment is not enough; firms need to manage training programs more effectively so that they can get the highest returns from their investment. Training alone is not the answer to a sustained competitive advantage for organizations. Training evaluation gives guidance to organizations on their investment on human capital investment because it is a means of determining whether or not the training has been of value to the business [7].

\section{Statement of the Problems}

Training is systematic, conspicuous and planned acquisition of ASKs; attitudes (i.e., what we need to feel), skills (i.e., what we need to do), and knowledge (what we need to know) that together lead to improved performance in a particular environment. It is about a permanent change in people's behaviors and action. Both the private and public sectors, regardless of types or nature, agree that training and development is necessary and vital to the growth and development of the business. Effective training creates an environment where trainees can: Learn the requisite ASKs, Practice applying the learned ASKs, and Receive constructive and timely feedback to improve performance in future. Human resource management (HRM) literature viewed training and development as an important activity that contributes to an organization's overall effectiveness in human resources management and that training and development is required to build and sustains an organization's competitive advantage via skills and knowledge enhancement [1].

Under Directorate of Research Facilities Management, There are more than 9 Research Station Managers. Almost all of these station managers are of agricultural educational background and have yet not taken courses/trainings on human resources management and other office administration related courses. Some of them are managing/administering about 300 permanent employees and plenty contract \& causal workers. It has been witnessed that most of these station managers lack basic human resources management skills and knowledge. This has led them to taking none procedural and biased actions against employees. This has in turn affected the moral and time of employees. Similarly, the number of complaints received by our office from research station workers is increasing from time to time, creating unwanted work load and in conveniences.

\section{Objectives of the Study}

To study perception of employees towards Training \& Development function

$>$ To study the training \& development human resource management and development administration prevailing in the organization

$>$ To analyze effectiveness of Training \& Development function

\section{Methodology}

The study was conducted in the research affairs office of Haramaya University Oromia Region, Ethiopia. This training were given on different topics of human resource management and development administration and office work plan \& report writing for research expert, managerial office and research station managers. It was conduct based on participatory learning approach where by the trainer interaction is mostly dominated by discussion with few lecture time. Besides this, the practical parts of the training sessions are design to include brief explanation on the purpose and significance each practical works. In general, there was a group discussion between the participants of the training. Experienced professional from Directorate of human resources development and management and planning office were delivering the training.

For a population of more than 300 employees working in research affairs office, a sample of $50(25 \%$ of population) respondents is taken using simple random sampling. The required data is collected from the sample respondents using a structured questionnaire. The most popular method which is used extensively for eliciting opinions and attitudes in research is the Likert method of summated ratings and it is used in the present study. The initial part of the questionnaire entails demographic characteristics of the respondents. The later part has 20 statements seeking a response over five point Likert scale. These 20 statements are designed based on research objectives that address different dimensions -Training Needs, Training Design, Trainer Performance, Training Evaluation, Trainee Performance, Satisfaction with Training \& Development and Developmental of human resources management administrations. The data is analyzed using various statistical measures. Causal analysis is used to identify the relationship between different dimensions of training with the help of correlation and regression tools. A statistical measure mean is also used in analyzing data.

\section{Results and Discussion}

First Objective of study was perception of employees towards Training \& Development function. Perception of employees toward training and development function is studied covering various dimensions like training needs, training design, trainer performance, trainee performance training evaluation and satisfaction with 
training programs.

\section{Determination of Training Needs}

Needs assessment is very important as the training \& development programs have to be designed based on the training needs identification. Training should be designed and delivered to meet the needs of all employees, and employees should perceive that they are being treated fairly and equitably with regard to the training they receive [8].

In the present study, it is a healthy sign that majority $(80 \%)$ of the respondents opined that training needs are determined based on employee requirement which is turn facilitates effective design of training program. If the training program addresses needs of trainees, he/she attains a high level of satisfaction and grades the training delivered as very effective [9].

\section{Training Design}

Training design refers to the degree to which the training has been designed and delivered in such a way that provides trainees the ability to apply learning on the job [12]. Training design dimension envisage effective design of training material, quality of manuals and schedule of training.

An empirical study [12] \& [11] on 30 industrial units revealed that the training design interventions have got the due attention of the industrial units and training design and implementation is significantly related to effectiveness of training. In the present study, $72 \%$ of the respondents agreed that training is effectively designed in the company, whereas only $4 \%$ disagreed that training design is effective and $24 \%$ are neutral. As majority of the respondents opines that training design is good, it can contribute to the effectiveness of training.

\section{Trainer Performance}

The performance of the trainer is an important factor that contributes to the effectiveness of the training and development. In this context, the organization has to take utmost care and attention in choosing the appropriate trainer and ensure that trainer can deliver the intended results. The effective trainer's performance requires that the trainer has to make the learner comfortable, emphasize the importance and constituents of the job, and its relationship to workflow, make the learners feel free to interact and ask questions, grab the attention and keep the learners engaged, find out what the learner already knows about his job or other jobs and understand the gap and explain things in a simple manner using examples which are familiar to the learners. The trainer has to choose appropriate methods based on the objectives and the learners ${ }^{e e}$ style.

Trainer performance dimension encompasses trainer delivery, use of suitable methods during training program. $74 \%$ of the respondents perceived that trainer performance is effective during training programs in the company while $22 \%$ are neutral and only $4 \%$ of the respondents are not satisfied with the performance of the trainer.

\section{Trainee Performance}

Through training \& development, motivational variables of recognition, achievement, growth, responsibility \& advancement are internalized and operationalized. It also helps in encouraging \& achieving self-development \& self-confidence, helps a person handle stress, tension, frustration \& conflict, provides the trainee an increase in salary, an avenue for growth \& a say in his/her own future. Training is a vital ingredient of the bundles of practices arising from research into high performance work systems (Ashton and Sung, 2002, cited in [15]. [14] Expressed that training and development is most effective in motivating and retaining high quality human resources within organizations when operationalized along with other high performance work practices to which it is interrelated, namely rewards and performance management. Training and development practices have a positive impact on preparing them to be more effective in their work, increasing their technical abilities, interpersonal abilities, teamwork, job confidence and work motivation

It is observed that $54 \%$ of respondents agreed that training positively contributes to increase in skills, performance and leads them to take up future assignments confidently $20 \%$ of respondents strongly agreed that training program benefits thems and $26 \%$ are neutral.

Table 1 Mean Scores of the Dimensions of Effectiveness of Training \& Development

\begin{tabular}{|l|l|l|l|l|}
\hline & Training Needs determination & Training Design & Trainer Performance & Trainee Performance \\
\hline Mean & 3.96 & 3.84 & 3.98 & 3.76 \\
\hline
\end{tabular}

Table 1 shows that the mean scores of all the dimensions of effectiveness of training \& development are pretty high. The mean score of trainer performance is relatively high with 3.98 closely followed by the mean score of training needs determination with 3.96 indicating relatively high level of satisfaction with these dimensions when compared to training design and trainee performance. 
Second objective of study training and development of human resource management and development administration prevailing in the organization Training and Development

Top management commitment towards development of employees, importance given to training programs, sponsoring employees to attend external training and well designed and widely shared training policy in the company determine training and development human resource management and development administration in the institution. Data was collected on these dimensions. $70 \%$ of respondents agreed that the organization has healthy training and development human resource management in the institution while $24 \%$ are neutral and $6 \%$ disagreed.

\section{Satisfaction with training \& development programs}

$60 \%$ of the respondents are satisfied with the training \& development programs as they provide an increase in salary and promotion to higher levels. This leads to higher job satisfaction and more commitment from the employees. Only $6 \%$ are not satisfied while $34 \%$ are neutral in terms of satisfaction with training \& development programs.

\section{Third Objective of study effectiveness of Training \& Development}

One important dimension that helps in determining the effectiveness of training \& development programs is training evaluation.

\section{Training Evaluation}

Training should be evaluated during the process. The effectiveness of any training program is determined not only by the successful acquisition of critical knowledge but also the ability to effectively transfer that knowledge to the performance environment [1], [4], [11], [7]]. Employees should be evaluated by comparing their newly acquired skills with the skills defined by the goals of the training program. Any discrepancies should be noted and adjustments have to be made to the training program to enable it to meet specified goals. Many training programs fall short of their expectations simply because the administrator fails to evaluate its progress until it was too late. Timely evaluation will prevent the training from straying from its goals.

In the present study, $58 \%$ of the respondents agreed that training is effectively evaluated in the company. $32 \%$ of respondents neither agreed nor disagreed with effective training evaluation and $10 \%$ are not satisfied with evaluation of the training programs. This indicates that there is scope to improve the effectiveness of training evaluation which is a very important component in the program.

\section{Effectiveness of training \& development programs}

Training effectiveness is based on the effective determination of training needs, training design, trainer performance and trainee performance. It is observed that $28 \%$ of respondents strongly agreed that training programs conducted in the company are effective. $60 \%$ of the respondents agreed that training programs are effective. Whereas only $4 \%$ are of different opinion that training programs are not effective and $8 \%$ are neutral in their opinion. It is a noteworthy feature that majority of the respondents perceived that the training \& development programs are effective. 
Table 2 Correlation between effectiveness of training and training dimensions

\begin{tabular}{|c|c|c|c|c|c|c|}
\hline & & $\begin{array}{l}\text { Training } \\
\text { Needs }\end{array}$ & \begin{tabular}{|l} 
Training \\
Design
\end{tabular} & $\begin{array}{l}\text { Trainer } \\
\text { Performance }\end{array}$ & $\begin{array}{l}\text { Trainee } \\
\text { Performance }\end{array}$ & $\begin{array}{l}\text { Training } \\
\text { effectiveness }\end{array}$ \\
\hline Training Needs & $\begin{array}{l}\text { Pearson } \\
\text { Correlation } \\
\text { Sig. (2-tailed) } \\
\text { N }\end{array}$ & 50 & $\begin{array}{l}.555^{* *} \\
.000 \\
50\end{array}$ & $\begin{array}{l}.381^{* *} \\
.006 \\
50\end{array}$ & $\begin{array}{l}.271 \\
057 \\
50\end{array}$ & $\begin{array}{l}.746^{* *} \\
.000 \\
50\end{array}$ \\
\hline Training Design & $\begin{array}{l}\text { Pearson } \\
\text { Correlation } \\
\text { Sig. (2-tailed) } \\
\mathrm{N}\end{array}$ & $\begin{array}{l}.555^{* *} \\
.000 \\
50\end{array}$ & 50 & $\begin{array}{l}.567^{* *} \\
.000 \\
50\end{array}$ & $\begin{array}{l}.334^{*} \\
.018 \\
50\end{array}$ & $\begin{array}{l}.735^{* *} \\
.000 \\
50\end{array}$ \\
\hline $\begin{array}{l}\text { Trainer } \\
\text { Performance }\end{array}$ & $\begin{array}{l}\text { Pearson } \\
\text { Correlation } \\
\text { Sig. (2-tailed) } \\
\text { N }\end{array}$ & $\begin{array}{l}.381^{* *} \\
.006 \\
50\end{array}$ & $\begin{array}{l}.567^{* *} \\
.000 \\
50\end{array}$ & 50 & $\begin{array}{l}.292^{*} \\
.039 \\
50\end{array}$ & $\begin{array}{l}.566^{* *} \\
.000 \\
50\end{array}$ \\
\hline $\begin{array}{l}\text { Trainee } \\
\text { Performance }\end{array}$ & $\begin{array}{l}\text { Pearson } \\
\text { Correlation } \\
\text { Sig. (2-tailed) } \\
\text { N }\end{array}$ & $\begin{array}{l}.271 \\
.057 \\
50\end{array}$ & $\begin{array}{l}.334^{*} \\
.018 \\
50\end{array}$ & $\begin{array}{l}.292^{*} \\
.039 \\
50\end{array}$ & 50 & $\begin{array}{l}.542^{* *} \\
.000 \\
50\end{array}$ \\
\hline $\begin{array}{l}\text { Training } \\
\text { effectiveness }\end{array}$ & $\begin{array}{l}\text { Pearson } \\
\text { Correlation } \\
\text { Sig. (2-tailed) } \\
\text { N }\end{array}$ & $\begin{array}{l}.746^{* *} \\
.000 \\
50\end{array}$ & $\begin{array}{l}.735^{* *} \\
.000 \\
50\end{array}$ & $\begin{array}{l}.566^{* *} \\
.000 \\
50\end{array}$ & $\begin{array}{l}.542^{* *} \\
.000 \\
50\end{array}$ & 50 \\
\hline
\end{tabular}

**. Correlation is significant at the 0.01 level (2-tailed).

*. Correlation is significant at the 0.05 level (2-tailed).

There is a positive correlation between all dimensions (training needs, training design, trainer performance, trainee performance) and training effectiveness. Training need is positively correlated with training effectiveness at 0.746 , Training design is positively correlated with training effectiveness at 0.735 , Trainer performance is positively correlated with training effectiveness at 0.566 and Trainee performance is also positively correlated with training effectiveness at 0.542 .

Among all dimensions, training needs and training design are more positively correlated with training effectiveness.

It is very clear that there is a positive correlation between the dimensions of training program and overall training effectiveness which is significant at 0.01 levels. This indicates that effective determination of training needs, good training design, efficient trainer and trainee performance will increase the effectiveness of the training \& development program.

Table 3 ANOVA

\begin{tabular}{|l|l|l|l|l|l|}
\hline Model & Sum of Squares & Df & Mean Square & F & Sig. \\
\hline $\begin{array}{l}1 \\
\text { Regression }\end{array}$ & 19.387 & 4 & 4.847 & 42.662 & $.000^{\mathrm{a}}$ \\
Residual & 5.113 & 45 & .114 & & \\
Total & 24.500 & 49 & & & \\
\hline
\end{tabular}

Predictors: (Constant), Trainee Performance, Training Needs, Trainer Performance, Training Design

Dependent Variable: Training effectiveness

Table 5.11 Regression analysis of training effectiveness

\begin{tabular}{|c|c|c|c|c|c|}
\hline \multirow[b]{2}{*}{ Model } & \multicolumn{2}{|c|}{ Unstandardized Coefficients } & \multirow{2}{*}{\begin{tabular}{|l} 
Standardized \\
Coefficients
\end{tabular}} & \multirow[b]{2}{*}{$\mathrm{T}$} & \multirow[b]{2}{*}{ Sig. } \\
\hline & $\mathrm{B}$ & Std. Error & & & \\
\hline $\begin{array}{ll}1 & \text { (Constant) } \\
\text { Training Needs } \\
\text { Training Design } \\
\text { Trainer Performance } \\
\text { Trainee Performance }\end{array}$ & $\begin{array}{l}.073 \\
.400 \\
.307 \\
.117 \\
.212\end{array}$ & $\begin{array}{l}.316 \\
.075 \\
.089 \\
.072 \\
.057\end{array}$ & $\begin{array}{l}.442 \\
.321 \\
.136 \\
.275\end{array}$ & $\begin{array}{l}.231 \\
5.348 \\
3.434 \\
1.623 \\
3.755\end{array}$ & $\begin{array}{l}.819 \\
.000 \\
.001 \\
.112 \\
.000\end{array}$ \\
\hline
\end{tabular}

a. Dependent Variable: Training effectiveness

Regression equation

$\mathrm{Y}=0.73+0.40 \mathrm{X} 1+0.307 \mathrm{X} 2+0.117 \mathrm{X} 3+0.212 \mathrm{X} 4$

Where, 
$\mathrm{Y}$ - Training Effectiveness X1 - Training Needs

X2 - Training Design

X3 - Trainer Performance X4 - Trainee Performance

Training effectiveness is a dependent variable and independent variables include training needs, training design, trainer performance and trainee performance. The F-value of 42.662 at a significant level of less than $1 \%$ indicates that dependent variable is significantly explained by changes in independent variables to a greater extent.

\section{Conclusion}

The Measurement of Effectiveness Training \& Development Programs in the case of Research Affairs Haramaya University, Oromia Region, Ethiopia Country - Empirical Study. Objectives of the Studies was perception of employees towards Training \& Development function, study the training \& development human resource management and development administration prevailing in the organization, to analyze effectiveness of Training \& Development function. Empirical studies, surveys, pre-post testing, questionnaire, observation are the common things found on various literatures. There are studies which focus on factors contributing to training effectiveness. Also some researches showed how to measure or evaluate effectiveness of training program. Effectiveness has been defined differently according to the demand of the study and interest of researchers.

Training and Development contributes in such a way that employees can enhance their dexterity. There is a causal relation between training and employee performance. Training helps organizations in achieving their strategic objectives and gives organizations a competitive edge. In this context, organizations train and develop their employees to the fullest advantage in order to enhance their effectiveness.

It is not just sufficient to conduct a training program. Organizations should evaluate whether training \& development programs are effective and producing desired results. Proper evaluation is the base to effective training. Based on the present study, it can be concluded that effectiveness of training \& development significantly depends on training needs determination, training design, trainer performance and trainee performance. In this context, appropriate attention has to be devoted for all the influencing dimensions that have a telling impact on training \& development effectiveness.

\section{REFERENCES}

[1] Afshan, S., Sobia, I., Kamran, A. \& Nasir, M. 2012. Impact of training on employee performance: a study of telecommunication sector in Pakistan. Interdisciplinary Journal of Contemporary Research in Business 4,6 .

[2] Alipour, M. \& Salehi, M. (2019), 'A Study of on the Job Training Effectiveness: Empirical Evidence of Iran', International Journal of Business and Management, Vol.4 No.11.

[3] Al-Nuseirat. A, \& Biygautane, M. (2014). 'The Impact of Effective Training on Organizational Performance in Dubai's Public Sector', Mohammed Bin Rashid School Of Government. Policy brief. Policy Brief No. 37. Feb 2014.

[4] AMOS, O.T. (2013), 'Staff Development Programs and Teachers' effectiveness In Secondary Schools: A Case Study of Ibadan South East Local Government Area of Oyo state'.

[5] Bhatia, A. (2014), 'Global Training \& Development trends \& Practices: An Overview', International Journal of Emerging Research in Management \&Technology ISSN: 2278- 9359 (Volume-3, Issue-8)

[6] Cole, G.A. 2012. Personnel and human resource management, 5th Ed. Continuum London: York Publishers.

[7] Healy, P. (2012), 'Training and public sector reform: an integrated approach', Public administration and Development, Vol. 21, No. 4, pp. 309-19

[8] Kabir, S.L., \& Baniamin, H.M. (2012), Civil Service Training in Bangladesh: An institutional Analysis of BPATC Role, Rhetoric and Reality, Dhaka: AH Development Publishing House.

[9] Kate Hutchings, Cherrie J. Zhu, Brain K, Cooper, Yiming Zhang and Sijun Shao (2019). "Perceptions of the effectiveness of training and development of ,grey-collar" workers in the Peoples Republic of China”, Human Resource Development International, volume12, number 3, pp.279-296.

[10] Lina Vyas. "Delivering Better Government: Assessing the Effectiveness of Public Service Training in India". Public Personnel Management, 33(3), 2014, 291-306.

[11] Manju.S \& Suresh B.H. "Training Design Interventions and Implications for the productivity Effectiveness" Synergy, 9(1), 2011, 52-68.

[12] NASC (2015), Impact of Professional Course on Management and Development on Performance of Class III officers of Government of Nepal, lalitpur, Nepal.

[13] NASC (2012), Impact of Advance Course on Management And Development on Performance of Class II Officers of Government of Nepal, lalitpur, Nepal.

[14] Schmidt Steven W (2019). "Employee demographics and job training satisfaction: the relationship 
between dimensions of diversity and satisfaction with job training", Human Resource Development International, volume 12, number 3, pp 297-312.

[15] Smith, A., and E. Smith. 2017. The role of training in the development of human resource management in Australian organizations. Human Resource Development International 10, no. 3: 263-79. 